\title{
Chinese women in colonial New South Wales: From absence to presence
}

KATE BAGNALL

\section{Introduction}

The history of early Chinese migration to New South Wales, and the other Australasian colonies, is usually told as a story of men. ${ }^{1}$ It is not hard to see why. Founded as a British penal colony in 1788, New South Wales became, over the next 60 years, home to a small and scattered number of Chinese men-mostly sailors, carpenters, cooks and labourers. Then, in 1848, a group of 120 Chinese men and boys arrived in Sydney-the first of around 3,500 indentured labourers from Amoy (廈門) who came to the colony over a six-year period to $1853 .{ }^{2}$ After the discovery of gold in New South Wales in 1851, this small Chinese population grew significantly, with as many as 12,000 Chinese arriving in New South Wales in one year alone (1858). ${ }^{3}$ Legislation restricted the number of Chinese immigrants between 1862 and 1867, yet over the 25 years from 1856 to 1880, almost 40,000 Chinese entered New South Wales. ${ }^{4}$ These goldrush immigrants were characterised by two things in particular: they were predominantly Cantonese and they were overwhelmingly male.

Colonial census statistics, which first differentiated 'natives of China' in 1856, give an indication of the imbalance of women and men in the Chinese population of New South Wales (Table 1). In 1856, the census recorded six female Chinese and 1,800 male Chinese in the colony. Five years later, in 1861, the male population had increased to 12,986 , while there were only two females. By 1871 , the number of female Chinese had grown to 12 , among a population of 7,208 males. Over the

\footnotetext{
1 For an overview of Chinese migration to colonial Australia, see C.Y. Choi, 'Early Chinese Migration to Australia 1861-1901', in Chinese Migration and Settlement in Australia (Sydney: Sydney University Press, 1975), 17-35; and Sing-wu Wang, 'Chinese Emigration to Australia', in The Organization of Chinese Emigration 18481888 (San Francisco: Chinese Materials and Research Aids Service Centre, 1978), 257-302. On Chinese settlement in Sydney and New South Wales, see Shirley Fitzgerald, Red Tape, Gold Scissors: The Story of Sydney's Chinese (Sydney: State Library of NSW Press, 1996); and Janis Wilton, Golden Threads: The Chinese in Regional New South Wales 1850-1950 (Sydney: Powerhouse Publishing, 2004).

2 Choi, 'Early Chinese Migration', 18; Maxine Darnell, 'Life and Labour for Indentured Chinese Shepherds in New South Wales, 1847-55', Journal of Australian Colonial History 6 (2004): 138-39.

3 Wang, 'Chinese Emigration to Australia', 268.

4 Wang, 'Chinese Emigration to Australia', 316.
} 
following decade- a period during which there were no restrictions on Chinese migration to the colony - the proportion of women to men grew significantly, even though numbers remained small; in 1881, the female Chinese population was 64, while the male population was 10,141 , making a ratio of one woman to 158 men. Census figures for the colonies of Victoria and Queensland record a similar imbalance in the sexes.

Twenty-eight years ago, writer Eric Rolls discussed the 1861 Chinese population statistics for New South Wales in Sojourners, the first of his extensive two-volume history of the Chinese in Australia. Rolls noted the presence of the two Chinese women living in New South Wales in 1861-'one on her own in Balmain' in Sydney, and the other living at East Maitland along with three Chinese men. Of the woman at Balmain, Rolls wrote: 'The lone woman is exceptional and inexplicable. What was she doing and how difficult was her life?'” This chapter is a step towards answering that question.

Table 1 Chinese population in the eastern colonies of Australia, 1856 to 1881

\begin{tabular}{|l|r|r|r|r|r|r|r|r|r|}
\hline & \multicolumn{3}{|c|}{ New South Wales } & \multicolumn{3}{c|}{ Victoria } & \multicolumn{3}{c|}{ Queensland } \\
\cline { 2 - 10 } & Females & Males & Total & Females & Males & Total & Females & Males & Total \\
\hline $1856^{\mathrm{a}}$ & 6 & 1,800 & 1,806 & 3 & 25,421 & 25,424 & n.a. & n.a. & n.a. \\
\hline $1861^{*}$ & 2 & 12,986 & 12,988 & 8 & 24,724 & 24,732 & 1 & 537 & 538 \\
\hline $1871^{\text {b }}$ & 12 & 7,208 & 7,220 & 31 & 17,795 & 17,826 & 8 & 2,621 & 2,629 \\
\hline 1881 & 64 & 10,141 & 10,205 & 164 & 11,795 & 11,959 & 23 & 11,206 & 11,229 \\
\hline
\end{tabular}

a Figures for Victoria are for 1857. No separate figures for Queensland are available for 1856 because, until 1859, it was part of the colony of New South Wales.

${ }^{b}$ Figures for Queensland are for 1868.

Source: 'The Chinese in Australia', Official Year Book of the Commonwealth of Australia (Melbourne: Commonwealth Bureau of Census and Statistics, 1925), 952-53.

In this article, I present short biographical sketches of four Chinese womenAh Happ, Ah Fie, Kim Linn and Sam Kue-who arrived in New South Wales from Hong Kong during the 1860s. These women were resident in New South Wales when the census was taken in 1871 and so together represented one-third of the officially recorded female Chinese population. My aim in compiling sketches of their lives is, at heart, a simple one: to give a name to some of the earliest Chinese women who made New South Wales their home, and to understand something of their lives. Social and historical conditions have meant that knowledge of these women, and others like them, has been both forgotten and overlooked within historical scholarship to date; indeed, recognition of their very presence within the

5 Eric Rolls, Sojourners: Flowers and the Wide Sea (Brisbane: University of Queensland Press, 1992), 172. Sojourners was recently published in Chinese as 艾瑞克·罗斯, 澳大利亚华人史 (1800-1888), trans. 张威, 中山大学出版社, 2017. 
colonial population of Australia has been overwhelmed by the numerical dominance of Chinese men. ${ }^{6}$ To date, there is still only a handful of histories that explicitly consider Chinese women in nineteenth-century Australasia. ${ }^{7}$

In the face of this erasure of Chinese women from the early history of the Chinese in colonial Australasia, and more broadly from the global history of Chinese migration during the nineteenth century, uncovering their identities and compiling even fragmentary microlevel accounts of these women's lives does something important. Their lives may be insignificant in the broad sweep of history, but, as Tonio Andrade and others have suggested, microhistorical and biographical approaches such as those used in this article populate the models and theories of global history with real people, anchoring the study of global processes to the reality of people's lives. ${ }^{8}$ In the words of Heather Streets-Salter: '[T]he stories that result demonstrate in concrete ways that the currents of world history have always involved ordinary people engaged in their own stories of survival, tragedy or victory.9 An approach such as Andrade's 'global microhistory' is also particularly useful when we consider questions of gender. The global phenomenon of nineteenth-century migration from southern China-which extended to sites across the Pacific including Australia, New Zealand, Canada and the United States, and to elsewhere around the worldcannot be fully understood without considering women, both those who migrated and those who remained at home, yet women's role in these migrations and the effects on their lives are often marginalised..$^{10}$ Global microhistories therefore offer an alternative methodology for a gendered history of the nineteenth-century Chinese diaspora, one in which women's lives can come more clearly into sight.

\footnotetext{
6 For more on this, see Kate Bagnall, 'Rewriting the History of Chinese Families in Nineteenth-Century Australia', Australian Historical Studies 42, No. 1 (March 2011): 62-77, doi.org/10.1080/1031461X.2010.538419. 7 See, for example, Julia Bradshaw, 'The Bride Could Speak No English: Chinese Women on the West Coast', in Golden Prospects: Chinese on the West Coast of New Zealand (Greymouth: West Coast Historical and Mechanical Society Inc., 2009), 123-40; Sophie Couchman, 'Chang Woo Gow: The Man and the Giant', in An Angel By the Water: Essays in Honour of Dennis Reginald O'Hoy, ed. Mike Butcher (Melbourne: Holland House Publishing, 2015), 85-101; Kate Bagnall, “'To his home at Jembaicumbene”: Women's Cross-Cultural Encounters on a Colonial Goldfield', in Migrant Cross-Cultural Encounters in Asia and the Pacific, eds Jacqueline Leckie, Angela McCarthy and Angela Wanhalla (London: Routledge, 2017), 56-75.

8 See Tonio Andrade, 'A Chinese Farmer, Two African Boys, and a Warlord: Toward a Global Microhistory', Journal of World History 21, No. 4 (2010): 573-91; Cao Yin, 'The Journey of Isser Singh: A Global Microhistory of a Sikh Policeman', Journal of Punjab Studies 21, No. 2 (Fall 2014): 325-53; and Phillip Guingona, 'The Sundry Acquaintances of Dr. Albino Z. Sycip: Exploring the Shanghai-Manila Connection, circa 1910-1940', Journal of World History 27, No. 1 (2016): 27-52, doi.org/10.1353/jwh.2016.0089. For an Australian example, see Kate Bagnall, 'Writing Home from China: Charles Allen's Transnational Childhood', in Migrant Lives: Australian Culture, Society and Identity, ed. Paul Longley Arthur (London: Anthem Press, 2018), 91-118, doi.org/10.2307/j.ctt1xhr5j8.9. 9 Heather Streets-Salter, 'The Local was Global: The Singapore Mutiny of 1915', Journal of World History 24, No. 3 (2013): 544, doi.org/10.1353/jwh.2013.0066.

10 On the history of women in overseas Chinese communities, see, for example, Woon Yuen-Fong, 'Between South China and British Columbia: Life Trajectories of Chinese women', BC Studies 156-57 (Winter/Spring 200708): 83-107; Adam McKeown, 'Transnational Chinese Families and Chinese Exclusion, 1875-1943', Journal of American Ethnic History 18, No. 2 (Winter 1999): 73-110; Judy Yung, Unbound Feet: A Social History of Chinese Women in San Francisco (Berkeley, CA: University of California Press, 1995).
} 


\section{Researching women: Sources and methods}

Researching the lives of Chinese women in colonial Australia has long seemed a near impossible task, for three main reasons. ${ }^{11}$ The first concerns colonial population statistics and the small numbers of Chinese women recorded therein. As historian Henry Chan noted more than 20 years ago, the topics of women, marriage and the family in Chinese Australian history were hardly touched on 'because of the assumption that there would not be a ... history [to write] given the demographics of the nineteenth-century Chinese communities in Australia'. ${ }^{12}$ The second reason concerns the question of for whom exactly we should be searching in the archives, and how. Searching for biographical information by name is a common practice within historical research, yet many individual Chinese women went unnamed in the historical record. How do we search without names, but how do we find names without searching? The third and closely related reason concerns the availability of and access to sources. It has long been acknowledged that the task of writing Chinese Australian history can be challenging because of the difficulty in locating sources, particularly those that present a Chinese perspective, and finding sources in which women's actions and voices are seen and heard is even more of a challenge. As Ann Laura Stoler notes in Along the Archival Grain: 'Knowing what one is after is not always enough.' ${ }^{\prime 3}$

There are, however, historical records that do document Chinese women's presence in nineteenth-century Australia, and we should not ignore the traces, or 'historical sediments', left by Chinese women and girls, even if these traces were not written by the women themselves. ${ }^{14}$ Instead, the fragmentary records of Chinese Australian women's lives necessitate different approaches. In this article, I demonstrate how the lives of Chinese women in colonial Australia can be recovered using three particular groups of sources: colonial censuses, historical newspapers and official records of births, deaths and marriages.

11 For an overview of the historiography, see Alanna Kamp, 'Chinese Australian Women in White Australia: Utilising Available Sources to Overcome the Challenge of "Invisibility", Chinese Southern Diaspora Studies 6 (2013): 75-101, chl-old.anu.edu.au/publications/csds/csds2013/csds2013_08.pdf.

12 H.D. Min-hsi Chan, 'A Decade of Achievement and Future Directions in Research on the History of the Chinese in Australia', in Histories of the Chinese in Australasia and the South Pacific, ed. Paul Macgregor (Melbourne: Museum of Chinese Australian History, 1995), 421-22.

13 Ann Laura Stoler, Along the Archival Grain: Epistemic Anxieties and Colonial Common Sense (Princeton, NJ: Princeton University Press, 2009), 9, doi.org/10.1515/9781400835478.

14 Sucheng Chan, 'Against All Odds: Chinese Female Migration and Family Formation on American Soil during the Early Twentieth Century', in Chinese American Transnationalism: The Flow of People, Resources, and Ideas between China and America during the Exclusion Era, ed. Sucheng Chan (Philadelphia: Temple University Press, 2006), 34-35. 


\section{Census}

New South Wales took a colony-wide population census each decade from 1861, in which Chinese people were counted based on their 'birthplace', 'nationality' or 'race'. ${ }^{15}$ These population figures are usually taken to demonstrate the absence of Chinese women from the colony, but they are also evidence of the presence of some women and of where they lived. The census shows that before 1881 most Chinese women in New South Wales were living beyond Sydney, the colony's capital and metropolitan centre. In 1856, the colony's six Chinese women lived in the districts of Parramatta/Liverpool, Goulburn, Hartley, Maitland (where one of the two women lived in the town of West Maitland) and Ipswich (where the woman lived in the town of Ipswich itself). ${ }^{16}$ Five years later, in 1861, one Chinese woman lived in the town of East Maitland and another in the Sydney suburb of Balmain (this is the woman Eric Rolls found 'inexplicable' because no Chinese men lived in Balmain along with her). In 1871, the population was divided between five female Chinese in Sydney and its suburbs and seven in rural districts. Of those in rural districts, one each lived at Dubbo, Orange and Raymond Terrace, while four lived on the goldfields: two at Jembaicumbene near Braidwood, one at Nerrigundah and one at Peel River near Nundle. The 1881 census does not provide details of the locations of the 64 Chinese females in the colony, other than to divide them thus: 41 in Sydney and its suburbs, eight in towns and villages of more than 100 inhabitants and 15 in rural areas.

\section{Colonial newspapers}

Alongside the census, newspapers and journals published across New South Wales-both in Sydney and in country towns-documented the presence of Chinese women in the colony. Because of their small numbers, Chinese women were a curiosity and newspapers reported their presence with a deal of interest. Consequently, historical newspapers provide one of the most significant sources for locating and identifying early Chinese women in the colony and learning about their lives. ${ }^{17}$ At their most basic, reports on Chinese women in the colonial press

15 The figures that follow are taken from NSW Census 1856 (Native Country), NSW Census 1861 (Nationality of the People), NSW Census 1871 (Nationality) and NSW Census 1881 (Birthplaces of the People). These historical censuses are available from the Historical Census and Colonial Data Archive at: hccda.ada.edu.au/regions/NSW. 16 The town of Ipswich, south-west of Brisbane in what is now Queensland, is included in the 1856 population figures for New South Wales because Queensland did not become a separate colony until 1859.

17 Many colonial newspapers are available in digital form through the National Library of Australia's Trove discovery service (trove.nla.gov.au/newspaper/). The full text of newspaper articles is searchable, meaning it is possible to search for relevant articles by using various terms for 'female Chinese' (such as 'Chinese woman', 'Chinese ladies', 'wife of a Chinaman', 'Chinese girl') or names (such as the names of women's husbands or their businesses). 
simply noted that a woman lived in a particular place. ${ }^{18}$ At other times, newspapers reported sightings of Chinese women in public — such as when they arrived to live in a particular town or when they travelled through a particular place, or even during a local natural disaster - with reports often commenting on their appearance, including their complexion, hair, clothes and, sometimes, their bound feet. ${ }^{19}$ Chinese women were also noted in the press because of the birth of a baby-often the 'first Chinese baby' born in a particular town. ${ }^{20}$ Newspaper correspondents, some of whom were women, also gained entrée to the households of well-to-do Chinese merchants in the city, and portrayed their wives, daughters and maid servants living cloistered lives, wearing exquisite outfits and elaborate hairdos, and being shy even among their female neighbours (see Figure 1). ${ }^{21}$

While colonial newspaper reports provide evidence of the presence of Chinese women and girls in New South Wales from the 1860s, many of these articles provide no easy way of identifying women as named individuals. Fortunately, however, some articles do provide personal names_albeit usually a husband's name_and with them the prospect of confirming women's identities through other records. ${ }^{22}$ The four biographical sketches I present in this article result from successfully correlating names and other personal details found in newspaper reports with the third group of sources_-official registrations of births, deaths and marriages.

18 'Bombala', Australian Town and Country Journal (22 June 1878): 39, nla.gov.au/nla.news-article70612648. (Earlier that year, the Manaro Mercury, and Cooma and Bombala Advertiser reported that two Chinese women with 'small feet' had taken up residence in Bombala: 'Two Chinese Ladies ...', Manaro Mercury, and Cooma and Bombala Advertiser (27 February 1878): 4, nla.gov.au/nla.news-article114515116.) For similar examples, see 'The Torres Straits Mail Steamer ...', Sydney Morning Herald (14 July 1879), nla.gov.au/nla.news-article13438397; and 'A Chinese Festival', Sydney Mail (19 February 1881): 286, nla.gov.au/nla.news-article161883295.

19 See, for example, 'Extraordinary Arrival', Goulburn Herald and Chronicle (31 August 1864): 2, nla.gov.au/ nla.news-article104609250; 'Chinese Ladies', Maitland Mercury (31 December 1868): 4, nla.gov.au/nla.newsarticle18734039; 'Destructive Fire in George-Street North', Sydney Morning Herald (30 January 1873): 6, nla. gov.au/nla.news-article13321177; 'Epitome of News', Armidale Express (30 April 1880): 3, nla.gov.au/nla.newsarticle192876998.

20 'First Chinese Native of Cooma', Manaro Mercury, and Cooma and Bombala Advertiser (16 July 1879): 2, nla. gov.au/nla.news-article114514061.

21 See, for example, 'Chinese Ladies Interviewed', Sydney Mail (15 February 1873): 219, nla.gov.au/nla.newsarticle162658804; 'Chinese New Year Festival in Sydney', Freeman's Journal [Sydney] (28 February 1874): 5, nla. gov.au/nla.news-article128810224; and 'Chinese Women in Sydney', Evening News [Sydney] (18 January 1878), nla.gov.au/nla.news-article107940323.

22 See, for example, 'Parkes', Australian Town and Country Journal [Sydney] (4 September 1875): 9, nla.gov.au/ nla.news-article70585116 (marriage of Yo Hey); 'Births, Marriages, and Deaths', Australian Town and Country Journal [Sydney] (15 July 1876), nla.gov.au/nla.news-article70602739 (birth of son to wife of Lee Hi See); 'A Peculiar Case', Goulburn Herald (25 November 1884): 2, nla.gov.au/nla.news-article103506312 (death of Chinese girl Qui Lang, servant to Hing Kee's wife). 


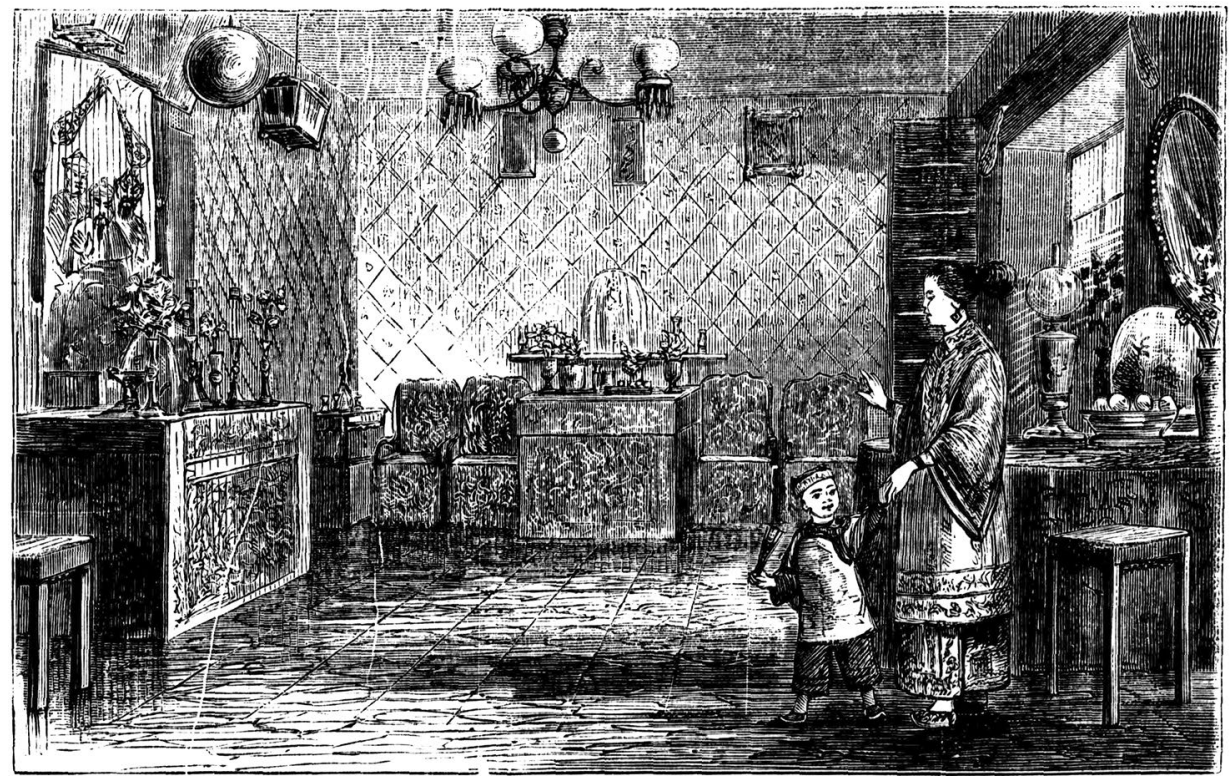

Figure 1 'A Chinese lady at home in Castlereagh-Street', Sydney Mail, 15 February 1879

Source: National Library of Australia, nla.gov.au/nla.news-article162808068.

\section{Birth, death and marriage records}

Official records of births, deaths and marriages - and other records relating to these major life events, such as baptism records, burial registers, wills and probate papers - provide fundamental pieces of biographical and genealogical information about Chinese women in colonial New South Wales. Birth records are particularly important as they are primary evidence of an individual woman's presence in the colony, providing not only biographical data, but also information about her marriage, the birth (and sometimes death) of her children and her mobility within the colony. Civil registration of births, deaths and marriages was introduced in New South Wales in $1856,{ }^{23}$ and we see in these records the efforts of colonial officials to regularise the names and identities of Chinese women, men and children and to record on paper chronological points in their personal biographies. ${ }^{24}$ The information provided by birth, death and marriage records can be inconsistent and incomplete, as shown in the women's stories that follow, but despite their imperfections, the information they provide is significant in the process of inserting individual, name-identified women into the early history of migration from southern China to Australia.

23 For an overview of the history of civil registration in New South Wales, see 'History of the Registry', NSW Registry of Births, Deaths and Marriages website (Sydney: Department of Justice), web.archive.org/web/20170528044633/ http://www.bdm.nsw.gov.au/Pages/about-us/history-of-the-registry.aspx [hereinafter NSW BDM].

24 On the peculiarities of Chinese Australian names, see Wilton, Golden Threads, 49-50. 


\section{Biographical sketches: Fragments of everyday lives}

The biographical sketches that follow focus on the everyday lives of four name-identified Chinese women who lived in New South Wales during the 1860s, 1870s and 1880s, pieced together from newspapers and records of births, deaths and marriages, together with other colonial sources. The earliest of these women to arrive in New South Wales, Ah Happ, was certainly in Sydney by 1863 , while the latest, Kim Linn, arrived around New Year in 1869. All four-Ah Happ, Ah Fie, Kim Linn and Sam Kue-were present when the colonial population was counted on 2 April 1871, so it is possible to match them to locations noted in that census. In 1871, Ah Happ was at Nelson's (Nelson) Bay, Ah Fie at Nundle, Kim Linn at Jembaicumbene on the Braidwood goldfields and Sam Kue at Sydney (Figure 2). The identities of the other eight female Chinese recorded in the 1871 census are yet to be confirmed. The census captured a record of each of these women at a particular time and a particular place, but their lives were not static. Like the many thousands of male migrants, these women were mobile and leaving their homes in southern China was just the beginning of a journey that would take them into some of the remotest corners of colonial New South Wales.

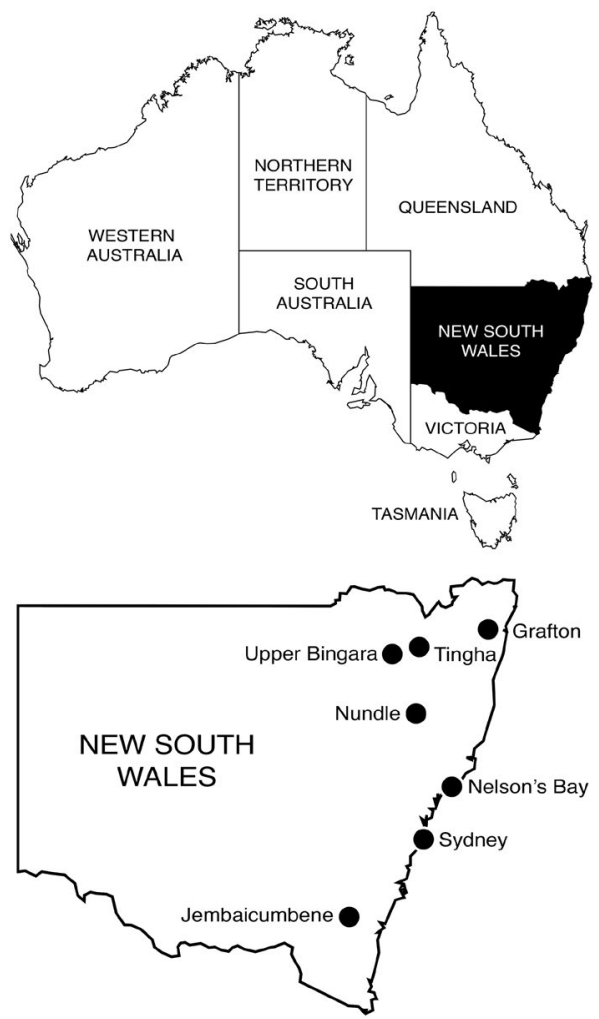

Figure 2 Places of residence of Ah Happ, Ah Fie, Kim Linn and Sam Kue in New South Wales 


\section{Ah Happ of Balmain and Nelson's Bay}

Ah Happ's name first appears in the colonial record in a brief article in the Sydney Morning Herald reporting on proceedings held at the Sydney Water Police Court. ${ }^{25}$ The article noted that, in April 1863, Ah Happ, a Chinese woman, took her employer, Cyril Cecil, to court for unpaid wages, claiming $£ 89 \mathrm{~s}$. $6 \mathrm{~d}$. for her services as a nurse in his household at Snail's Bay, Balmain. Yearly wages for a domestic servant at the time were between $£ 20$ and $£ 30$, so this was a substantial sum, likely earned over a number of months. ${ }^{26}$ The court dismissed her claim, but the events surrounding the case were perhaps what propelled Ah Happ's life in a new direction. A year after the court case, Ah Happ had moved from suburban Balmain to the isolated shores of Port Stephens, about 160 kilometres to the north-east of Sydney, and she was no longer a nursemaid but a mother.

Ah Happ gave birth to her first baby, a son named George, at Port Stephens on 22 May 1864. ${ }^{27}$ She was 28 years old and the baby's father, a fisherman named Ah Jong, was 40 years old; they were both from Canton. At Port Stephens, Ah Happ and Ah Jong lived in a small fishing village, not far from the Nelson's Bay lighthouse; it was a remote settlement comprising one European family and about 80 Chinese residents who lived in bark and logs huts near the beach. ${ }^{28}$ The Chinese fishermen cured the fish they caught, sending it by coaster to Chinese merchants in Sydney for sale to their countrymen who were on the way to the goldfields. ${ }^{29}$

An article in the Maitland Mercury newspaper in June 1865 noted the presence of Ah Happ and her baby among this population at Nelson's Bay, saying:

The settlement is honoured with the presence of a Chinese woman, and a young Australian-born Chinaman. The woman speaks a little English, and with evident pride told the Rev. Mr. Thackeray that she is Missus Ah Chong. The interesting youngster was introduced to the reverend gentleman by its fond mamma and proud papa. ${ }^{30}$

At the time of this report, Ah Happ would have been pregnant with her second baby, another boy, Charles, who was born on 13 October 1865. Two more sons followed: Frederick, born on 23 December 1868, and William, born on 13 August 1870. ${ }^{31}$ The Maitland Mercury article noted that Ah Happ spoke some English-as might be expected if she had previously worked as a nursemaid for a British family-but it appears she could not write, in either English or Chinese. She signed baby Charles's

25 'Water Police Court', Sydney Morning Herald (24 April 1863): 8, nla.gov.au/nla.news-article13077496.

26 Beverly Kingston, My Wife, My Daughter and Poor Mary Ann: Women and Work in Australia (Sydney: Thomas Nelson (Australia) Ltd, 1975), 45.

27 NSW BDM, Birth registration for George Ah Jong, 22 May 1864, Port Stephens, 14199/1864.

28 'The Condemned Chinaman', Maitland Mercury (6 June 1865): 3, nla.gov.au/nla.news-article18706606.

29 'Chinese Fishermen', Illustrated Sydney News (30 May 1874), nla.gov.au/nla.new-article63105356.

30 'The Condemned Chinaman', Maitland Mercury.

31 NSW BDM, Birth registrations for: Charles Ah Jong, 13 October 1865, Port Stephens, 14549/1865; Frederick Ah Jong, 23 December 1868, Port Stephens, 17290; William Ah Jong, 13 August 1870, Nelson's Bay, 16342/1870. 
birth registration with an ' $\mathrm{X}$ ', as did Ah Jong when registering the births of their other sons. The boys' birth certificates consistently stated that Ah Happ and Ah Jong were married in China in 1859.

Ah Happ's first three babies were delivered by a Mrs Glover-presumably, Margaret Glover née Dow, wife of the Nelson's Bay lighthouse keeper, William Glover. A Dr White also assisted with Charles's birth in 1865, while the final baby, William, arrived with his father as the only other person in attendance. It seems Ah Happ and Margaret Glover may well have been the only non-Aboriginal women living in the Nelson's Bay area during the 1860s. Margaret was mother to her own large family, the youngest four of whom were born at Port Stephens at a similar time to Ah Happ's children. ${ }^{32}$

After the birth of Ah Happ's youngest son in 1870, there is little further evidence to be found of her or her husband, Ah Jong, in New South Wales. It is most likely that the Chinese woman recorded in the 1871 census in the Raymond Terrace police district—an area that included Port Stephens—was Ah Happ. Then, there was a list of unclaimed telegraph messages in Sydney in 1874 that included one for 'Ah Chong, Nelson's Bay'. ${ }^{33}$ Beyond that I have uncovered nothing else. With no satisfying conclusion to the story of Ah Happ's life in the colony, what, then, of its beginnings? When and how did she arrive? How did she come to be working for the Cecil family? And, if she was living in Balmain in 1863, could she also be Eric Rolls's 'inexplicable' lone Chinese woman living there in 1861?

Ah Happ's employer, Cyril Cecil, was an English-born merchant who, in the late 1850s and early 1860s, was engaged in trade between Hong Kong and New South Wales. ${ }^{34}$ He had married Louisa Walker, an Englishwoman, in Melbourne in $1859^{35}$ and, in the early years of their marriage, they made their home variously in Melbourne, Sydney and Hong Kong. Louisa gave birth to their first child in Sydney in $1860 .{ }^{36}$ A second child was born in Hong Kong in July 1861, before the family returned to Sydney in $1862 .{ }^{37}$ A pregnant Louisa Cecil, together with an infant

32 Denise Gaudion, 'GLOVER ---- PORT STEPHENS', Rootsweb: AUS-NSW-Hunter-Valley-L [Online resource], 12 September 2001, accessed from: archiver.rootsweb.ancestry.com/th/read/AUS-NSW-Hunter-Valley/2001-09/ 1000279619 [site discontinued]; 'Obituary', Raymond Terrace Examiner (7 April 1932): 3, nla.gov.au/nla.newsarticle133105315.

33 'Miscellaneous Items', Australian Town and Country Journal [Sydney] (10 January 1874): 11, nla.gov.au/nla. news-article70471508.

34 Bryan Kinna, John Gill and Beatrice Stefanovic, 'Cyril Alexander Cecil: A Short History', March 2011, Typescript in possession of the author.

35 'Marriage registration of Cyril Alexander David and Louisa Elizabeth Walker, Melbourne', 2098/1859, Victoria Births, Deaths and Marriages [Online] (Melbourne: State Government of Victoria, 2019).

36 NSW BDM, Birth registration of Martha E.M. Cecil, Sydney, 752/1860.

37 Bryan Kinna, Correspondence with the author, 18 June 2012. For an illustration of nursemaids in Hong Kong, see 'Chinese Nursemaids on the Parade-Ground, Hong Kong', Illustrated London News (17 October 1857): 385. 
and servant, arrived in Sydney in mid July 1862 on the Madras from Hong Kong. ${ }^{38}$ Cyril Cecil, also with a child and servant, arrived in Sydney three months later on the Bombay, just in time for Louisa to give birth to their third child at Balmain on 23 September $1862 .{ }^{39}$

The scant details from Ah Happ's court case have her working for the Cecils at Balmain prior to April 1863, so it is possible she was one of the two servants who arrived with the family on their return from Hong Kong in 1862. Conversely, Ah Happ may have already been working as a domestic servant in Balmain and was employed by the Cecils as a nursemaid following their arrival from Hong Kong and the birth of their third child. In the first scenario, the dates do not match for Ah Happ to be the lone Chinese woman living at Balmain in 1861; in the second, they do. Either way, despite the little we know about the beginning and the end of Ah Happ's life in New South Wales, her story provides a possible explanation for the 'inexplicable' Chinese woman in Balmain in 1861: she could have been working as a servant in a white household. Another possibility is that this 'lone' Chinese woman was, in fact, married to a British man. ${ }^{40}$

\section{Ah Fie of Happy Valley, near Nundle, and Upper Bingara}

In September 1864, three months after Ah Happ became a mother at Port Stephens, the Chinese community at Bowling Alley Point, on the Peel River goldfields near Nundle in the north-east of New South Wales, celebrated the arrival of a Chinese woman in their midst. According to a report from the Tamworth Examiner republished in various colonial papers, she was the wife of a storekeeper at nearby Happy Valley. ${ }^{41}$ The couple had come to Bowling Alley Point to celebrate their 're-marriage' - one might guess after the woman had come out from China to join her husband. She was described as being 'rather low in stature' (that is, short) and dressing 'remarkably well, neat and fashionable_quite in English style'. The local Chinese held a great celebration in her honour - with roast pigs, fowls and ducks, and much wine and spirits - and took up a subscription of the remarkable sum of $£ 180$ as a gift to her.

\footnotetext{
38 'Shipping', Sydney Morning Herald (14 July 1862): 4, nla.gov.au/nla.news-article13231310; 'Passenger list for Madras, 11 July 1862, Sydney', in New South Wales, Australia, Unassisted Immigrant Passenger Lists, 1826-1922, Ancestry.com [Online database] (Provo, UT, 2007).

39 'Passenger list for Bombay [incorrectly transcribed as Boundry], 11 September 1862', in New South Wales, Australia, Unassisted Immigrant Passenger Lists, 1826-1922, Ancestry.com [Online database] (Provo, UT, 2007); 'Shipping: Arrivals', Empire [Sydney] (11 September 1862): 4, nla.gov.au/nla.news-article60480780; NSW BDM, Birth registration for Cyril Mansell Cecil, Sydney, Balmain, 2415/1862; 'Births', Sydney Morning Herald (26 September 1862): 1, nla.gov.au/nla.news-article13234714.

40 Such a situation was quite possible. Historian Pauline Rule has identified that the first Chinese woman in the colony of Victoria was a Christian woman from Macau who was married to an English sailor. She arrived in Melbourne in 1856. Pauline Rule, Personal communication with the author, January 2013.

41 For example, 'Chinese Marriage', Newcastle Chronicle (24 September 1864): 2, nla.gov.au/nla.newsarticle128920990; and 'Chinese Marriage', Sydney Morning Herald (14 October 1864): 5, nla.gov.au/nla.newsarticle30934811.
} 
The following year the Chinese at Nundle celebrated again, after the birth of a baby boy to 'Mrs. Ah Foo, wife of Mr. Ah Foo, storekeeper, of Nundle'. ${ }^{42}$ According to the Tamworth Examiner, this baby was 'no half and half affair, but a thorough Mongolian', and it seems likely therefore the baby's parents were the same couple whose marriage was celebrated a year earlier. The Examiner's report on the baby's birth noted that he was only the second baby born in the colony whose mother and father were both Chinese. If Ah Happ's oldest son, George, born in May 1864, was the first Chinese baby in New South Wales, this claim may well have been true. According to the baby's birth registration, he was Ah Cong Ah Foo, born on 24 April 1865 at Happy Valley, Nundle, the son of Ah Fie. ${ }^{43}$

At the time of Ah Cong's birth in 1865, Ah Fie was 32 years old. Her husband, Sam Ah Foo, was 41 years old. They were both Cantonese and, according to Ah Cong's birth registration, were married in Sydney in 1864. Working backwards from Ah Cong's date of birth, it seems Ah Fie may have arrived in Sydney in the middle months of 1864 . At age 31 , she was not a young bride, suggesting she may have been betrothed or married to Sam Ah Foo in China in their youth, only coming to join him later in New South Wales.

With no other children born to her, we lose track of Ah Fie until the middle of 1871, when she was reported as living at Upper Bingara, a goldmining settlement about 200 kilometres further north from Nundle. The 1871 census, taken in early April, recorded a Chinese woman - presumably Ah Fie-living on the Peel River goldfields at Nundle, so it seems the family may have moved to Upper Bingara soon after. In July 1871, Ah Fie, Ah Foo and their son were travelling and stayed the night in the small town of Cobbadah, about 25 kilometres south of Upper Bingara. As this was apparently 'a strange sight for all', Ah Fie's visit received a lengthy write-up by the local Cobbadah newspaper correspondent. ${ }^{44}$ Commenting on her appearance, the correspondent noted that she was small and quite fair and that her feet were 'not as we have heard they are' (presumably meaning they were not bound). She 'talked English quite fluently', understanding much better than did her husband. Their son, now aged six, spoke English and Chinese, went to school, could read a little and knew several hymns, which he sang to please his mother. Ah Foo was said to be 'very attentive' to his wife and 'very fond' of his son. The report noted that Ah Foo kept a store and butcher's shop at Upper Bingara, but perhaps

42 'Birth of a Chinese in the Colony' [reprinted from the Tamworth Examiner, 15 July 1865], Maitland Mercury (18 July 1865): 3, nla.gov.au/nla.news-article18696236. The report notes that in July 1865 the baby was baptised as 'Henry Sydney' by Church of England minister the Reverend Mr Whinfield from Tamworth. Reverend Whinfield made periodic visits to the mining communities around Nundle; see 'Notes of a Trip Through the Northern District', Maitland Mercury (17 March 1866): 2, nla.gov.au/nla.news-article18712816.

43 NSW BDM, Birth registration for Ah Cong Ah Foo, 24 April 1865, Happy Valley, Nundle, 15489/1865.

44 'Cobbedah', Armidale Express (22 July 1871): 5, nla.gov.au/nla.news-article189260769. 
with her better English skills, Ah Fie might have had a substantial role in running the business; a post office directory for 1872 lists both Ah Foo and Mrs Ah Foo as storekeepers at Upper Bingara. ${ }^{45}$

The 1871 report of the family's visit to Cobbadah noted one other significant thing about Ah Fie-that she had, for some time, been suffering with bad eyes. Her eyesight was mentioned again, two years later, in a traveller's account of Upper Bingara published in the Newcastle Chronicle. ${ }^{46}$ This report is the last mention of Ah Fie that I have found in the colonial record. Writing in June 1873, the correspondent noted that the Chinese at Upper Bingara lived in a village of 50 or more residents, with gardens well stocked with fruit trees and vegetables. Among their number was 'a Chinese lady — a real one, too', who was blind. Despite this, the correspondent noted she had a 'small, but happy family' and 'all around her treated her with more than ordinary kindness, in consequence of the loss she has sustained'. Ah Fie would have been about 40 years old.

\section{Kim Linn of Jembaicumbene and Sydney}

Nineteen-year-old Kim Linn came to New South Wales from Hong Kong in late 1868, travelling on the Sunshine to Melbourne and then on the Hero from Melbourne to Sydney. ${ }^{47}$ She travelled as part of a group of Chinese women: a woman aged 28, a three-year-old girl and three young women aged between 16 and 19. In Melbourne, Kim Linn was met by Ah How, a storekeeper from Jembaicumbene on the Braidwood goldfields south of Sydney, and together they travelled to his home as husband and wife. An article in the Braidwood Dispatch, reprinted in a Sydney newspaper, recorded Kim Linn's arrival at Jembaicumbene in January 1869, noting how a local Chinese storekeeper had 'just returned from Melbourne with a Chinese lady whom his parents selected for him in his native land and sent out to become his wife'. ${ }^{48}$ Ah How was a well-known and respected member of the Chinese community at Jembaicumbene. He had arrived in the colony as a young man in the late 1850s and had subsequently gone into business as a storekeeper, profiting from supplying the substantial Chinese population who worked the diggings along Jembaicumbene Creek. In May 1872, Ah How was naturalised as a British subject under the name Ralph Ah How, and the following year he was granted a publican's licence.

45 Greville's Official Post Office Directory of New South Wales (Sydney: Greville \& Co., 1872).

46 'Newcastle to Bingera', Newcastle Chronicle (26 June 1873): 4, nla.gov.au/nla.news-article111145663.

47 For more on Kim Linn's life in New South Wales, see Kate Bagnall, “'To his home at Jembaicumbene”.

48 'The Progress of Mongolian Colonisation', Sydney Morning Herald (8 January 1896): 5, nla.gov.au/nla.newsarticle13187496. 
Kim Linn gave birth to her first baby, a boy, at Jembaicumbene on 19 August $1869 .{ }^{49}$ He was premature and died soon after birth. ${ }^{50}$ She lost her second baby, tooanother boy, who was born on 7 June 1870 and died two days later. ${ }^{51}$ Both births, and that of her third child, were attended by an Irish neighbour, Mary Callaghan. Kim Linn's third baby, a girl named Lune Zee, was born on 14 May $1871 .{ }^{52} \mathrm{Kim}$ Linn would have been heavily pregnant with Lune Zee when the census was taken in early April 1871, and we can assume Kim Linn was one of the two Chinese females recorded at Jembaicumbene by the census that year (the other woman's identity remains unknown). Baby Lune Zee was followed by two brothers, One King (b. 13 August 1873) and John (b. 16 January 1876), who were delivered by a local midwife, Jane Helman. ${ }^{53}$

Kim Linn's sixth baby was born not at Jembaicumbene, but in Sydney. It appears that, with Jembaicumbene's waning fortunes, including a severe drought in the middle years of the 1870s, the family moved to Sydney, where they lived in Cambridge Street in The Rocks. It was there, on 30 September 1878, that Kim Linn gave birth to baby Albert, attended by a Dr Wright and a Mrs Hong. ${ }^{54}$ On the birth certificates of her Jembaicumbene babies, Kim Linn's name was recorded as 'Gum Leon' or 'Kim Linn'. By the time of Albert's birth in Sydney, however, she had acquired a new name: Elizabeth Gum Lin. Documents dated the following year give her name as Mary Elizabeth Ah How.

Ah How died of lung disease, aged 48, on 24 October 1879, leaving Kim Linn a widow with four young children (aged one, three, six and eight) and not yet 30 years old. ${ }^{55}$ Ah How was buried at Sydney's Rookwood Cemetery and his remains were later exhumed and returned to China. Ah How's probate documents, which named Kim Linn as his beneficiary, are almost the last documentary record of the family in New South Wales. The final, intriguing trace of them comes in the form of a death certificate from 1925, which records that one Johnnie Ah Howe, aged 50, died at Lower Campbell Street, Sydney. ${ }^{56}$ Johnnie Ah Howe had been born at Braidwood to father Ralph Ah How and mother Mary, and it is almost certain he was Kim Linn's final Jembaicumbene baby, born in January 1876. The death

49 NSW BDM, Birth registration for unnamed baby Ah How, Jembaicumbene, 1869, 7837/1869.

50 NSW BDM, Death registration for unnamed baby Ah How, Jembaicumbene, 1869, 3222/1869.

51 NSW BDM, Birth registration for unnamed baby Ah How, Jembaicumbene, 1870, 7591/1870; Death registration for unnamed baby Ah How, Jembaicumbene, 1870, 3050/1871.

52 NSW BDM, Birth registration for Lune Zee Ah How, Jembaicumbene, 1871, 8035/1871.

53 NSW BDM, Birth registration for One King Ah How, Jembaicumbene, 1873, 8183/1873; Birth registration

for John Ah How, Jembaicumbene, 1876, 8747/1876.

54 NSW BDM, Birth registration for Albert Ah How, Sydney, 1878, 2756/1878.

55 NSW BDM, Death registration for Ralph Ah How, Sydney, 1879, 1804/1879.

56 NSW BDM, Death registration for Johnnie Ah Howe, Sydney, 1925, 15860/1925. 
certificate stated that Johnnie had married in China at the age of 30 and had three children there, suggesting that, after Ah How's death, Kim Linn had returned to China with her young family.

\section{Sam Kue of Sydney, Grafton and Tingha}

Described as 'one of the first Chinese ladies to land in the Antipodes', Sam Kue came to New South Wales in the late 1860s as the wife of a merchant, John Ah See (亞四), who was also known as Tse Yet Chong (謝日昌). ${ }^{57}$ At the time of Sam Kue's arrival in New South Wales, her husband worked in the import-export firm of Tai Yick \& Company (泰盆) in Sydney. ${ }^{58}$ Sam Kue was more than a decade younger than her husband; she was born into a family named Kwok (郭) in Hong Kong in the later years of the 1840s, while he was born in Hoiping (開本) in Canton province in the early 1830 s.

Sam Kue was recorded as being 20 years old when she gave birth to the couple's first child, a daughter (later known as Sarah), at George Street, Sydney, on 23 May 1870. The baby's birth was attended by a Mrs Cavanagh. ${ }^{59}$ On census night in April 1871, baby Sarah would have been nearing her first birthday; was she perhaps counted alongside her mother as one of the four female Chinese in the City of Sydney? A second baby, a son named James (known as Tse Tsan Tai, 謝纘泰), was born in Sydney on 16 May 1872. ${ }^{60}$ From the birth certificates of these and subsequent children, it is not clear when or where Sam Kue and John Ah See had married, as the details given vary considerably. The 1870 birth certificate of their first daughter stated the couple was married in Sydney in 1866, while their last child's birth certificate, from 1882, stated they were married on 10 July 1867 in Hong Kong. Sam Kue's name was also recorded on these birth certificates in a number of ways: Sam Que, Sam, Mary Sangow and Sam Kue.

\footnotetext{
57 Tse Tsan Tai, The Chinese Republic: Secret History of the Revolution (Hong Kong: South China Morning Post, 1924), 6. See also Chesney Duncan, Tse Tsan Tai: His Political \& Journalistic Career-A Brief Record (London: Globe Encyclopaedia Company, 1917), 8.

58 Details of the history of the Tse/Ah See family can be found in Tse, The Chinese Republic, 6-7; John Fitzgerald, 'Revolution and Respectability: Chinese Masons in Australian History', in Connected Worlds: History in Transnational Perspective, eds Ann Curthoys and Marilyn Lake (Canberra: ANU Press, 2005), 89-110; and Rodney Noonan, 'Grafton to Guangzhou: The Revolutionary Journey of Tse Tsan Tai', Journal of Intercultural Studies 27, Nos 1-2 (February-May 2006): 101-15, doi.org/10.1080/07256860600607827.

59 NSW BDM, Birth registration of Ah See, 23 May 1870, George Street, Sydney, 1438/1870.

60 NSW BDM, Birth registration of Tan Hi See, Sydney, 1366/1872. A number of newspaper reports noted that James Ah See/Tse Tsan Tai was born in Grafton, but this was not correct. See, for example, 'Chinese Revolution', Glen Innes Examiner (27 September 1932): 7, nla.gov.au/nla.news-article184600422; 'Grafton Boy', Northern Star [Lismore] (27 September 1932): 8, nla.gov.au/nla.news-article94302747.
} 
In the mid 1870s, the family moved from Sydney to Grafton, a major town on the Clarence River in the far north-east of New South Wales. In fact, it seems likely they moved there in late 1874, as a shipping notice for the PS Agnes Irving, which arrived at Grafton on 3 December 1874, noted a 'Mr. and Mrs. Ah See and 2 children' among the paddle-steamer's passengers from Sydney. ${ }^{61}$ In Grafton, John Ah See ran a fruit shop and general store in the town's main street, Prince Street, and the family lived in a residence behind the shop. ${ }^{62}$

In 1876, Sam Kue gave birth to a second son, Thomas (known as Tse Tsan Ip, 謝纘葉, and Tse Tsi Shau, 謝子修). When Thomas was still a small baby, at the end of July 1876, the family was caught up in the most disastrous flood in Grafton's living memory. A report in the Clarence and Richmond Examiner, the premises of which were next door to the Ah Sees' store and home, told of the fearful night the family spent as the floodwaters rose along Prince Street:

Even our next door neighbour, a chinaman, a chinawoman, and three children were to be seen through their window all the livelong night contending with the ruthless foe for life. ${ }^{63}$

The following day the family was rescued by staff of the Examiner and they spent several days in the upper floor of the newspaper office, surviving on provisions salvaged from Ah See's store, until the floodwater subsided enough for the Ah Sees to return to their own single-storey home. ${ }^{64}$ Ah See's losses were calculated at $£ 50 .{ }^{65}$

Two more children were born to Sam Kue and John Ah See in Grafton: Samuel, born in 1878, and Lizzie, born in $1880 .{ }^{66}$ Around this time, the family became Christians and, on 1 November 1879, the eldest four children-Sarah, James, Thomas and Samuel - were baptised into the Church of England by Archdeacon C.C. Greenaway. Sam Kue and John Ah See were also later baptised.

In the early 1880s, the family moved to Tingha, a small town 200 kilometres inland from Grafton. Sam Kue's sixth and final baby, a daughter named Mary, was born at Tingha on 30 March $1882 .{ }^{67}$ Sam Kue was then 32 years old. Mary's

61 'Shipping', Grafton Argus and Clarence River General Advertiser (4 December 1874): 2, nla.gov.au/nla.newsarticle235019264.

62 'An Ex-Grafton Student', Clarence and Richmond Examiner [Grafton] (24 April 1915): 4, nla.gov.au/nla.newsarticle61643786.

63 'Most Disastrous Flood in the Clarence River', Clarence and Richmond Examiner [Grafton] (25 July 1876):

2, nla.gov.au/nla.news-article61905808. See also 'Story of Floods', Daily Examiner [Grafton] (18 August 1945): 3, nla.gov.au/nla.news-article195744209.

64 'Tse Tsan Tai', Daily Examiner [Grafton] (24 September 1932): 4, nla.gov.au/nla.news-article193557260.

65 'Deluge at Grafton', Glen Innes Examiner (26 July 1876): 2, nla.gov.au/nla.news-article217828484.

66 NSW BDM, Birth registrations of Thomas Ah See, Grafton, 12109/1876; Samuel Ah See, Grafton, 13251/1878; Lizzie Ah See, Grafton, 14995/1880.

67 NSW BDM, Birth registration of Mary Ah See, 30 March 1882, Tingha, 19861/1882. 
birth was attended by a Mrs Suey—most likely Margaret Suey née Battersby. ${ }^{68}$ Little information can be found about the life of the Ah See family in Tingha, with a notable exception being a report of a visit to Tingha in March 1885 . The writer noted:

We interviewed one of the Chinese ladies (there being two) that live here, and saw two of her six children, the others going to the Public school. We found Mrs. Ah See very agreeable, anxious to tell about her family, and she seemed very fairly satisfied with her lot. I believe one of her sons is one of the brightest boys in the school. ${ }^{69}$

It is likely the two children at home were five-year-old Lizzie and three-year-old Mary, and that the bright schoolboy was Sam Kue's first son, James, then aged 13. Under his Chinese name of Tse Tsan Tai, James Ah See went on to become a leading political and social reformer in China in the 1890s and early 1900s. He also co-founded Hong Kong's South China Morning Post newspaper in 1903 and is reputed to have produced the first political cartoon by a Chinese. ${ }^{70}$

In one of his many writings - a history of the Chinese revolution published in Hong Kong in 1924-Tse Tsan Tai described his family's background and his early life in New South Wales, as well as the family's eventual return to Hong Kong in 1887. We therefore know that Sam Kue-with her family of three daughters (aged five, seven and 17) and three sons (aged nine, 11 and 15)—left Tingha to return to Hong Kong, arriving there on 20 May 1887. The family was welcomed by John Ah See's 'old friends' on their arrival and, according to Tse Tsan Tai, they soon found themselves 'at home in a strange city with strange surroundings'. Although Tse Tsan Tai's account does not provide further details of Sam Kue's life after the family returned to Hong Kong, it does reveal that Sam Kue was still alive in 1924 and still a Christian: 'As for my mother,' he wrote, 'she is a good and pious soul, and will soon see her 80th birthday, if God be pleased.' By that time, Sam Kue had been a widow for more than 20 years, following the death of John Ah See in 1903 at age 73, at their residence on Praya East in present-day Wan Chai, Hong Kong. ${ }^{11}$

68 'SUEY (LUM SUEY) James', Heritage Futures Database [Online] (Armidale, NSW: Heritage Futures Research Centre, University of New England), hfrc.une.edu.au/heritagefutures/index.html; 'Obituary', Tingha Advocate (26 September 1924): 2, nla.gov.au/nla.news-article176010548.

69 'Notes on a Northern Tour', Sydney Morning Herald (2 March 1885): 4, nla.gov.au/nla.news-article13576689.

70 See Elizabeth Sinn, 'Tse Tsan Tai', in Dictionary of Hong Kong Biography, eds May Holdsworth and Christopher Munn (Hong Kong: HKU Press, 2012); Gary Cheung, 'The Revolutionary Beginnings of the South China Morning Post', South China Morning Post (5 October 2013), www.scmp.com/news/hong-kong/article/1324605/ revolutionary-beginnings-south-china-morning-post.

71 'The Late Mr. Tse Yet Chong', Evening News [Sydney] (16 April 1903): 7, nla.gov.au/nla.news-article1 13416883. 


\section{Conclusion}

In this article, I have sought to bring the question of gender to bear on the history of Chinese migration to nineteenth-century Australia through the approach of microhistorical biography. The four biographical sketches of Chinese women in colonial New South Wales presented here contain frustrating gaps and much supposition, and they raise many unanswered questions, but even so, telling these stories remains important. In searching out and compiling even fragmentary narratives of their lives, we start to give these Chinese women, and others like them, a place within the history of the Chinese in colonial Australia. The small numbers of Chinese women in colonial Australia, and the scattered and fragmentary nature of our sources about them, mean there are particular challenges in uncovering and writing about their lives. To date, these challenges have meant Chinese women have been largely written out of Chinese Australian histories and of broader global histories of nineteenth-century Chinese migration.

As we seek to redress this omission as historians, it is particularly important to use women's names, because when women's names do not appear, in either our sources or our writing, we come to expect to be unable to find anything more about them. We stop looking for them, we stop asking questions and we fall back on stereotypes about women's lives in the past. Most of the women whose lives were affected by migration from southern China during the second half of the nineteenth century-as migrants or as wives, mothers or daughters of migrant men-will remain anonymous. But naming their names and telling their stories as individuals where we can are powerful steps in shifting our thinking from unknown to known, and from absence to presence, as we continue to uncover the ways that women were part of the global history of the nineteenth-century Chinese diaspora. 
This text is taken from Australian Journal of Biography and History: No. 3, 2020, published 2020 by ANU Press, The Australian National University, Canberra, Australia.

doi.org/10.22459/AJBH.2020.01 